Sciences

Vol. 07, No. 01, pp. 109-118, March 2014

\title{
THE EFFECT OF COOLING RATE ON MECHANICAL PROPERTIES OF CARBON STEEL (St 35)
}

\author{
Jenan Mohammed Nagie \\ Assistant Lecturer \\ Mechanical Department, Institute of Technology - Baghdad / Iraq \\ E-mail: najejenan@yahoo.com \\ (Received: 26/6/2012; Accepted: 17/7/2013)
}

\begin{abstract}
This paper is aimed to study the effect of cooling rate on mechanical properties of Steel 35. Specimens prepared to apply tensile, torsion, impact and hardness tests.
\end{abstract}

Many prepared specimens heat treated at $\left(850^{\circ} \mathrm{C}\right)$ for one hour and subsequently were cooled by three different media [Water-Air-furnace] to show the effect of Medias cooling rate on mechanical properties. Microstructures of all specimens examined before and after heat treatment by an optical microscopy.

To figure the phases obtained after heat treatment and its effect on the mechanical properties Experimental results have shown that the microstructure of steel can be changed and significantly improved by varying line cooling rate thus, improving one property will effect on the others because of the relationship between all properties.

In water media tensile, torsion and hardness improved while impact results reduced. Air media contributed in improving most of the mechanical properties because of grain size homogeneity. At furnace media ductility and impact improved.

Keywords: Carbon Steel, Heat treatment, cooling rate and mechanical properties.

\section{INTRODUCTION}

Mechanical properties of steels are strongly connected to their microstructure obtained after heat treatment. These are generally performed in order to achieve good hardness, toughness, tensile strength with sufficient ductility.

Heat treatment of steel is the process of heating and cooling of carbon steel to change the steels physical and mechanical properties without changing the original shape and size. Therefore it becomes necessary to control heating and cooling of metals to alter their physical and mechanical properties It 'soften associated with increasing the strength of the steel, but it can also be used to alter certain manufacturability objectives such as improves machinability, 
formability, restore ductility etc. Thus heat treating is a very useful process to help other manufacturing processes and also improve product performance by increasing strength or provides other desirable characteristics ${ }^{(1)}$.

Currently there is a strong interest in the effect of cooling rate on the mechanical properties and microstructure of industrial processed Steel ${ }^{(2)}$, the influence of cooling rate on the microstructure of Steel $_{35}$ has been shown that water quenching produces Martensitic phase structure and in contract the slower air cooling results Ferrite and pearlite and also in furnace cooling but with the large grain size and heat treatment had the effect on torsion resistance which is mainly used for determination the modules of rigidity of material also during this test the shear behavior of material during elastic and plastic limit can be studied material deform elasticity until reaching yield point during elastic limit the distribution of shear stress will be zero at the center and maximum periphery also during this limit the shear is linearly proportional to shear strain. While during plastic limit the material deforms plastically because Torsion test specimen is not subjected to necking as in tension or barreling as in compression. Torsion test carry out on axial loading and little work on torsion (3).

Carbon increases the hardenability of steels by transforming the formation of pearlite and ferrite to martensitic courage's the formation of martensitic at slower cooling rates ${ }^{(4)}$.

The Charpy impact test, is destructive mechanical test, it's a standardized high strainrate test which determines the amount of energy absorbed by a material during fracture. This absorbed energy is a measure of a given material's toughness ${ }^{(5)}$.

\section{EXPERIMENTAL PROCEDURE}

The Experimental part is summarized as follows:-

\section{1- Metal Selection}

To specify the chemical composition of carbon steel (St35), its chemical analysis is indicated in Table (1) which was conducted by ARL Spectrometer in the specialized institution of engineering industries of Industry ministry.

\section{2- Preparation of Test Specimen}

Many specimens of steel used according to the standard specification for testing (ASTM) were prepared by machining process. The test specimen dimension is shown in fig (1).

\section{3- Categorization of Specimens}

After finishing the preparation process of the steel specimens (cutting the bar and machining process) the specimens were arranging into four groups as shown in Table (2).

\section{4) Heat Treatment}


Heat treatment was implemented on specimens groups (B, C, D) in Table (2)including heating the specimen to evaluated temperature for one hour and cooling at different rates, group (B) is cooled in water, group (C) cooled in air, and group (D) cooled in furnace.

\section{5) Test and Examinations}

\section{Microstructure Test}

Microstructure examination was implemented on specimen in the Table (2). The specimens were prepared as follow:

a) Grinding the specimen by emery paper no. $(180,240,400,800 \& 1000)$ with use of water.

b) Polishing operation by use a special polishing cloth with use of alumina solution $\left(A L_{2} \mathrm{O}_{3}\right)$, the particle size is $(0.3 \mu)$.

c) Developing solution for the structure by using Nital solution (2\% nitric acid $\mathrm{HNO}_{3}$ with 98\% methyl)

d) Photographing the microstructure by program microscope type (metallurgical microscope MTJ Corporation

\section{2-hardenss}

In this work, the hardness of steel for all specimens was done by using Vickers method and the result calculated according the equation below $\mathrm{HV}=1.8544 * \mathrm{~F} / \mathrm{d}^{2}$

Where $(\mathrm{F})$ : is the force applied to the diamond in (Kilograms).

(d): the indepater diameter (Square Millimeters).

Hardness results are shown in Table (3).

\section{3-tensile test}

By using (Instron machine 1195) at a speed of $2 \mathrm{~mm} / \mathrm{min}$, the specimens were prepared according to the ASTM shown in fig.(1-B ), Tensile test implemented for all specimen in Table (2) to determine the tensile strength prosperities, The obtained results are shown in Table (3).

\section{4-Torsion test}

The specimens in table (2) were subject to torsion test. The large twisting angle of scratched line we see a large amount of plastic deformation this angle represented the relation between a twist angle and the force which used on each specimen. The yield Torque (T) and yield angle of twist $\theta$ were determined from the elastic zone $\theta, \gamma$ and modules of rigidity $(G)$ were calculated by using the following formulas

$\tau=\frac{16 T}{\pi d 2}$

where

$\tau=$ shear stress in $\mathrm{N} / \mathrm{mm}^{2}$ 
$\mathrm{T}=$ torque $\mathrm{N} . \mathrm{mm}$

$\mathrm{Y}=\frac{\theta r}{L}$

Where

$\Theta=$ twist angle in $\mathrm{rad}$

$\theta=N * d * \frac{\pi}{180}$ -

$\mathrm{L}=$ specimen gauge length in $\mathrm{mm}$

$\mathrm{r}=$ specimen radius

$\mathrm{G}=\frac{\tau}{Y}$

Where

$\mathrm{G}=$ modulus of rigidity

$\mathrm{T}=\mathrm{F}^{*} \mathrm{r}[\mathrm{N} \cdot \mathrm{m}]$

$\tau=\frac{\mathrm{T} . \mathrm{r}}{\mathrm{J}}\left[\mathrm{N} / \mathrm{mm}^{2}\right]$

The experimental results for specimen's (A, B, C and D) respectively are shown in Fig (3).

Results of torsion are shown in Table (3) and fig. (4), (5)

\section{5) Impact Test.}

To determine the impact strength for all specimens sharbey test implemented to measure the energy required to break a material under impact loading.

Impact stress equation was implemented to calculate the metal strength the results are shown in Table (3)

$\frac{E}{A}=\sigma \mathrm{a} \mathrm{kg} \cdot \mathrm{m} / \mathrm{cm}^{2}$

A: specimen area in $\mathrm{cm}^{2}$

E: Energy in Kg. m

$\sigma a=$ metal strength

$\mathrm{E}=\mathrm{W} \mathrm{L}(\operatorname{COS} \beta-\operatorname{COS} \alpha)$

W: Mass of hammer in kilogram.

L: length in centimeter.

$\alpha$ : Angle of fall in degree.

$\beta$ : Angles at the end of the swing in degree.

\section{DISCUSSION}

From Table (3) which represent all results for testing specimens we see that, the specimen group (B) has low torsion strength comparing with strength of other group (A, C, D) 
respectively as shown in Table (3), because of the small number of cycles give small value of twist angle that cause the fail.

On the other hand the hardness, impact and tensile stress was high, because of forming the Austenite phase by the heat treatment, which obtained it wherein heating specimen to $\left(850 \mathrm{C}^{\circ}\right)$ then quenching in water. Then the transformed occurs to get fine needle structure which called Martensite, it was hard but brittle ${ }^{(2)}$.

The plastic depth is important factor where gives the amount of plastic deformation which consider very useful for heat treated metal. Always, observing the less plastic deformation at the specimen which has maximum value of torsion.

The specimen (D) has high torsion strength, as appear in Fig (3), and where the fail happens when the specimen reaching to a large number of cycles.

This proves; the specimen (D) owns a large amount of plastically deformation when it is subjected to torsion load. But hardness and impact was low because cooling rat was low in furnace therefore, the transformed Austenite into Ferrite and Pearlite by precipitate as laminated form ${ }^{(12)}$.

The specimen (C) give high value of torsion strength and impact comparing with the specimen without heat treated. Because the normalizing heat treated cause rearing meant of the laminated Ferrite and Pearlite structure ${ }^{(13)}$.

Hence, we can improve the desirable Mechanical properties from through control on cooling rate.

The photographs of microstructure of specimens (A, B, C, and D) are shown in Fig (2).

\section{CONCLUSIONS}

From the various results to obtain during the

1. Mechanical properties which desirable and applications required we should go for a suitable heat treatment processes.

2. Heat treatment contributes to improving the mechanical properties such hardness, ductility and toughness.

3. Mechanical properties varies are depending upon heat treatment processes variety.

\section{REFERENCES}

1. Metalkunde, Feb.16, 2011, "Heat Treatment of Steel under Metal Processing”, www. Metarullagy for dummies. 
2. M. B. Ndaliman, 2006, Assessment of Mechanical Properties of Medium Carbon Steel under Different Quenching Media", Department of Mechanical Engineering, Federal University of Technology Minna, Nigeria , AU J.T. 10 (2),pp. 100-104

3. A.G.F. Alabi,T.K. Ajiboye, H. D. Olusegun, (2010). "Effect of the cooling rate on torsion strength and hardness of stress \& microstructure", Journal of Minerals \& Materials Characterization \& Engineering jmmce.org, Vol. 10, No.3, pp.299308

4. Bhaskar Chandra Kandpal, AgnayChutani, AmitGulia, Harsimran, ChandanSadanna, 2011 “A Review On Jominy Test And Determination Of Effect Of Alloying Elements On Hardenability Of Steel Using Jominy End Quench Test”, Mechanical Engineering, ITM University, Gurgaon, India ,International Journal of Advances in Engineering \& Technology, Vol. 1, pp.65-71.

5. World Steel Association and the University of Liverpool, (C) 2002-2011 World Steel Association.

6. ISO 6507-1: 2005 "Metallic materials - Vickers hardness test - Part 1: Test method".

7. ASTM E384-10e2: Standard method for Vickers hardness of metallic materials.

8. H. S. K., 2001, "Finite Element Analysis of Torsional Deformation", Materials Science and Engineering A299, pp.305-308.

9. Jacobs James A, Kilduff Thomas, (2005). "Engineering Materials Technology", (5th ed.)Pearson Prentice Hall. pp. 153-155,

10. Kurishita H, Kayano H, Narui M, Yamazaki M, Kano Y, Shibahara I, (1993)."Effects of V-notch dimensions on Charpy impact test results for differently sized miniature specimens of ferritic steel". Materials Transactions - JIM , Japan Institute of Metals, Materials Transactions, Vol. 34, 1993, pp. 1042-1052

11. ASTM A370, "Standard Test Methods and Definitions for Mechanical Testing of Steel Products".

12. Bello, K.A., Hassan, S.B., and M. Abduwahab, 2007 "Effects of Tempering on the Microstructure and Mechanical Properties of Low Carbon, Low-Alloy Martensitic Steel”, Journal of Applied Sciences Research, 3(12): 1719-1723

13. Adnan calik, 2009 "Effect of Cooling Rate on Hardness and Microstructure of AISI 12020,Aisl 10404 and Aisl 1060 Steel",. 
Table (1): Chemical composition of steel.

\begin{tabular}{|c|c|c|c|c|c|c|c|c|c|}
\hline $\begin{array}{c}\text { Element } \\
\text { wt } \%\end{array}$ & $\mathrm{C}$ & $\mathrm{Mn}$ & $\mathrm{Si}$ & $\mathrm{Ni}$ & $\mathrm{Cr}$ & $\mathrm{Mo}$ & $\mathrm{S}$ & $\mathrm{P}$ & $\mathrm{Fe}$ \\
\hline Actual & 0.39 & 0.57 & 0.18 & - & 0.07 & - & - & - & \\
\hline Standard & $0.32-0.39$ & $0.5-0.6$ & 0.4 & - & - & - & 0.045 & 0.095 & \\
\hline
\end{tabular}

Table (2): Categorization of specimen.

\begin{tabular}{|c|c|}
\hline Specimen symbol & State of specimen \\
\hline A & Specimen without heat treatment $($ as received $)$ \\
\hline B & heated to $\left(850^{\circ} \mathrm{C}\right)$, for one hour and water quenched \\
\hline C & heated to $\left(850^{\circ} \mathrm{C}\right)$, for one hour and air cooled \\
\hline D & heated to $\left(850^{\circ} \mathrm{C}\right)$, for one hour and furnace cooled \\
\hline
\end{tabular}

Table (3): Tests results of mechanical properties for tested specimens.

\begin{tabular}{|c|c|c|c|c|c|c|}
\hline Conditions & $\begin{array}{c}\mathrm{HV} \\
\text { Hardness } \\
\left(\mathrm{Kg} / \mathrm{mm}^{2}\right)\end{array}$ & $\begin{array}{l}\text { Torsion } \\
\text { Strength } \\
\left(\mathrm{Kg} / \mathrm{mm}^{2}\right)\end{array}$ & $\begin{array}{c}\text { Impact } \\
\text { Strength } \\
\left(\text { Kg.m/ } / \mathrm{cm}^{2}\right)\end{array}$ & $\begin{array}{l}\text { Yield } \\
\text { strength } \\
(\mathrm{Mpa})\end{array}$ & $\begin{array}{c}\text { Ultimate } \\
\text { strength } \\
\text { (Mpa) }\end{array}$ & $\begin{array}{c}\text { Elongation } \\
\%\end{array}$ \\
\hline as received & 132 & 67.4 & 11.0 & 492 & 701 & 20 \\
\hline $\begin{array}{c}\text { water } \\
\text { quenched }\end{array}$ & 556 & 87 & 8.6 & - & 885 & 18 \\
\hline air cooled & 210 & 45 & 43.0 & 505 & 702 & 11 \\
\hline $\begin{array}{ll}\text { (D) } & \text { furnace } \\
\text { cooled }\end{array}$ & 155 & 52.5 & 80.3 & 317 & 496 & 25 \\
\hline
\end{tabular}

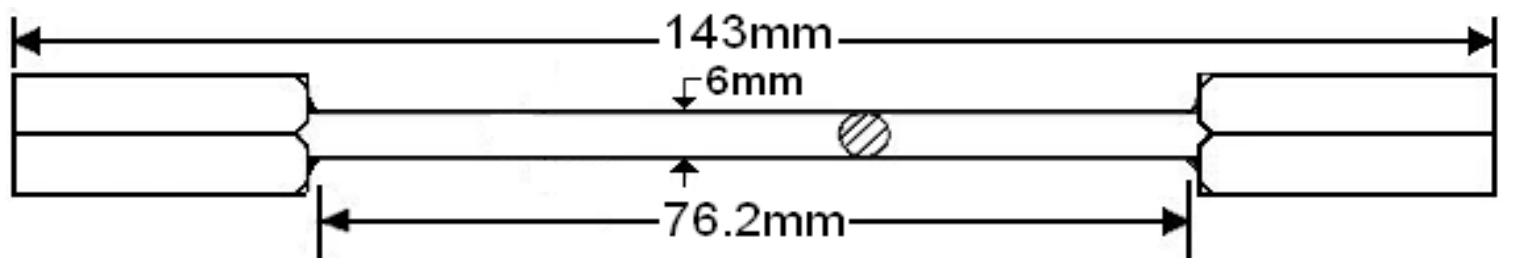

Sample (A) torsion specimen

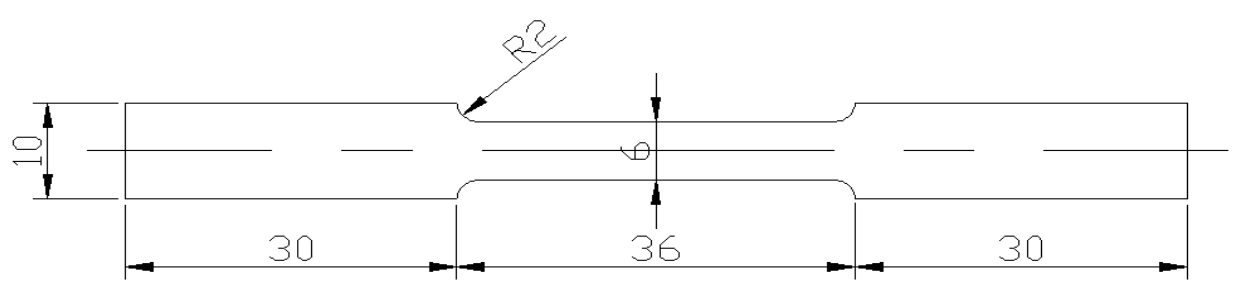

Sample (B) tensile specimen 


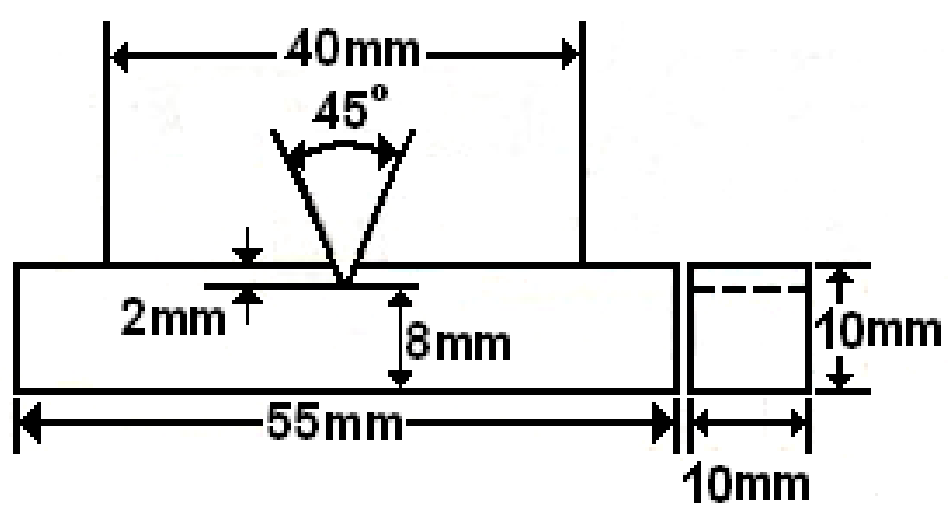

Sample (C) Impact specimen

Figure (1): sketch of testing specimens.

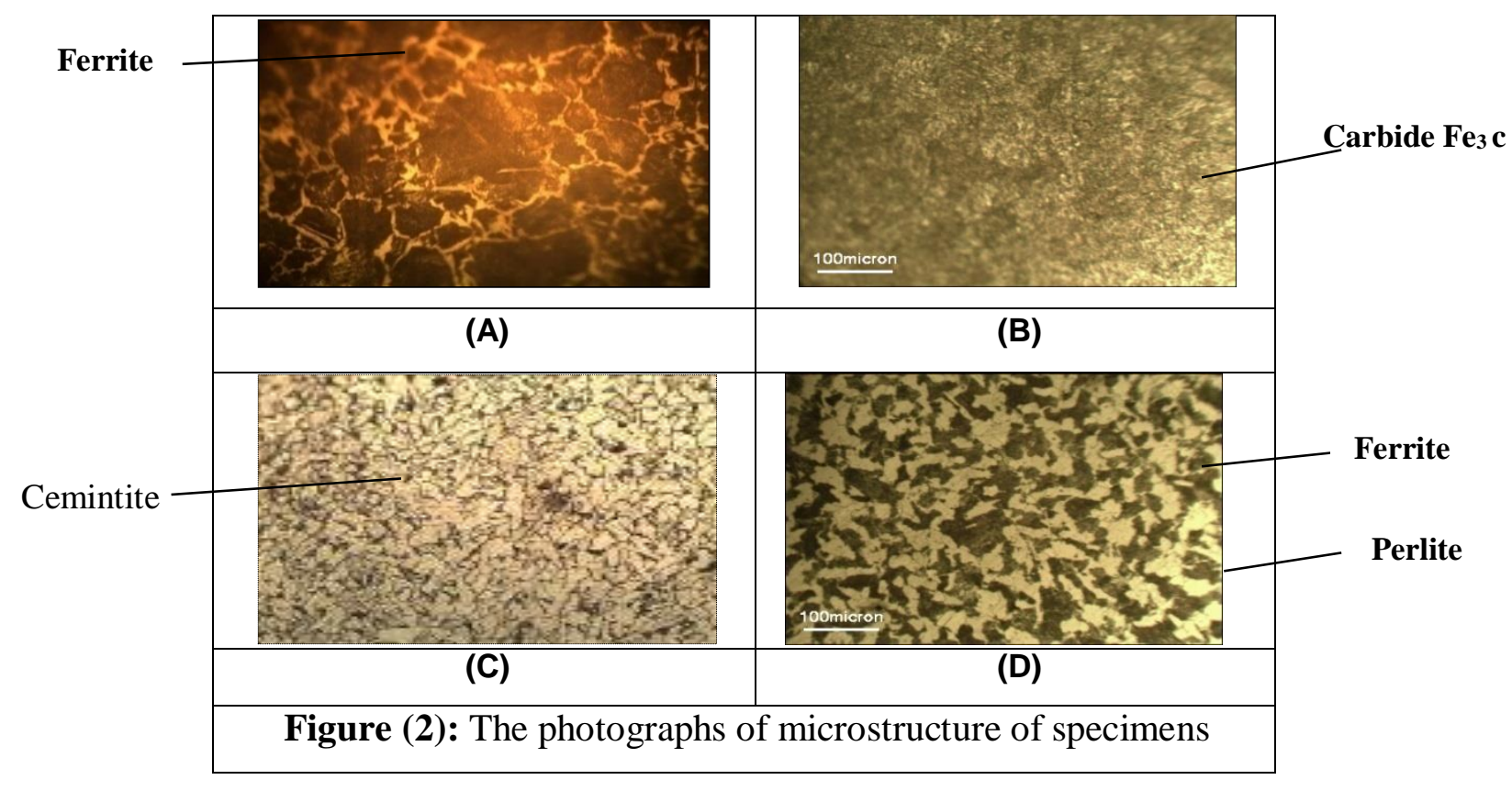

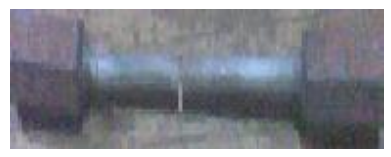

(A)

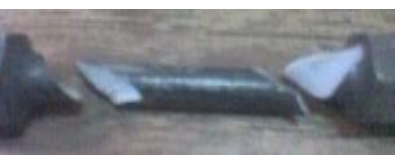

(B)

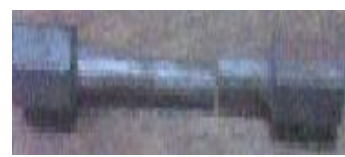

(C)

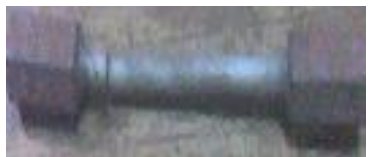

(D)

Figure (3): The photos show fracture shape experienced Specimens. 


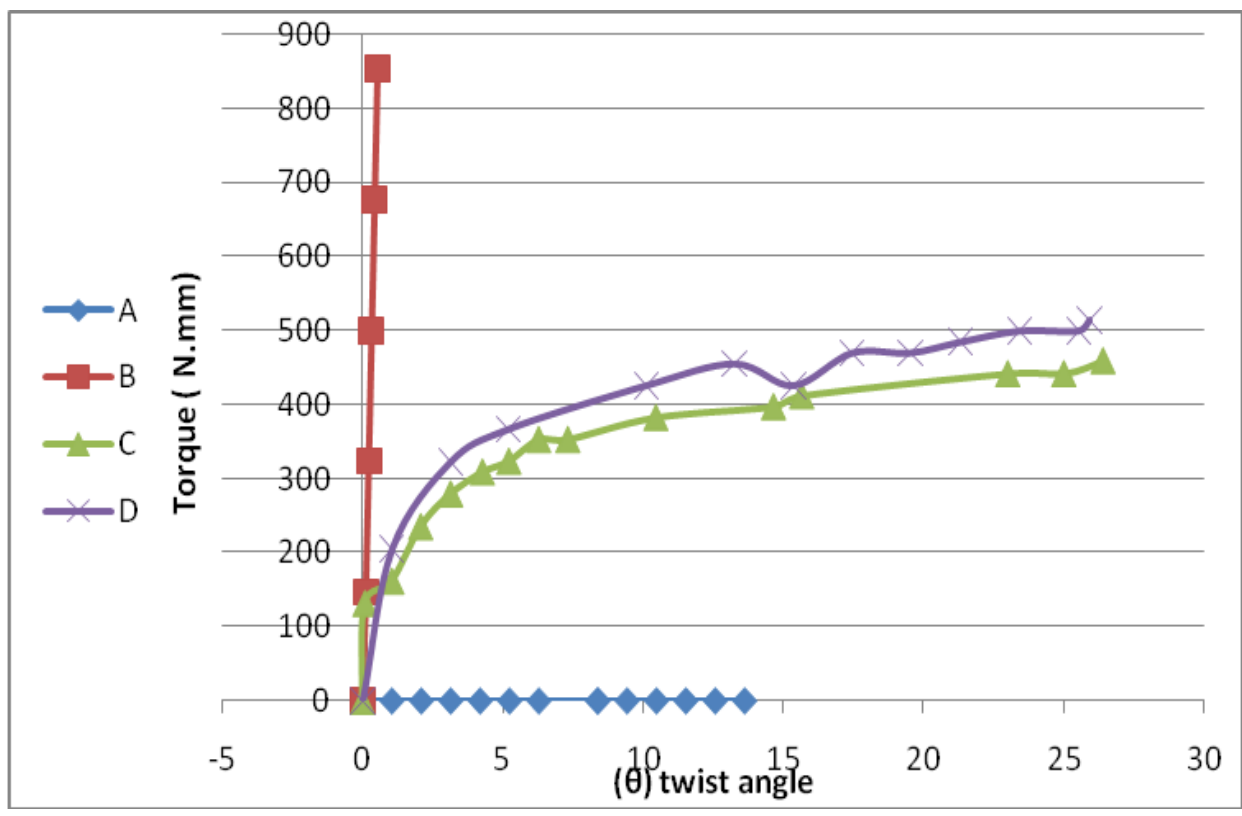

Figure (4): Relationships between Torque and twist angle.

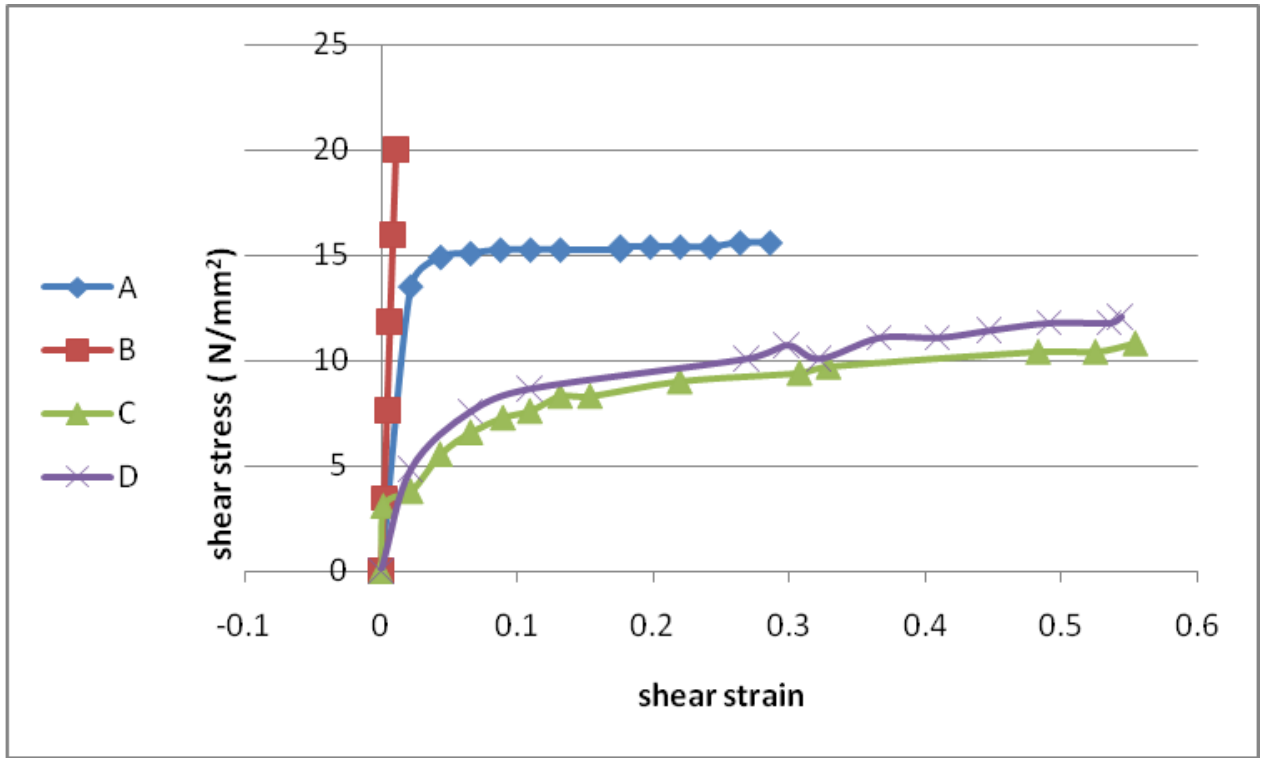

Figure (5): Relationship between sheer stress and sheer strain. 


\title{
St 35 تأثير معدل التبريد على الخواص الميكانيكية لفولاذ كاريوني
}

\author{
جنان محمد ناجي

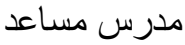 \\ معهد تكنولوجيا/ بغداد
}

الخلاصــة

يهدف البحث الى دراسة تأثيرمعدل التبريد على الخواص الميكانيكية للفولاذ كاربوني (St 35) حيث تم

تصنيع عينات اختبار (الثندواللي والصدمة والصلادة) ثم اجريت معاملات حرارية متضمنة تسخين المعدن الى درجة حرارة (850º C) لمدة ساعة ثم التبريدفي ثلاث أوساط مختلفة ( الماء ـ الهواء ـ الفرن).

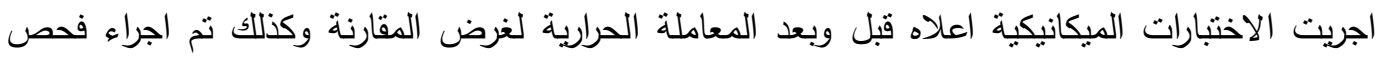

لللبنية المجهرية باستخدام المجهر الضوئي للتعرف على الاطوار التي تم الحصول عليها لبيان تاثيرها على الخواص اعلاه.

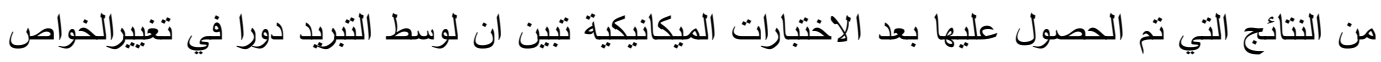

الميكانيكية وان تغيير احدها سيؤثز على الخاصية الاخرى. فقد زادت قيمة الصلادة وقوة الثد واللي بينما قلت قابلية الصدمة في الوسط المائي بينما حدث عكس هذة النتائج في التبريد بالفرن اما عند التبريد بالهواءتحسنت اكثر الخواص بسبب التجانس في حجم الحبيبات وتحسنت خواص مطيلية وقوة صدمة المعدن. 